\title{
ANALISIS WACANA RUBRIK RESENSI PADA SURAT KABAR SOLOPOS EDISI JANUARI-DESEMBER 2017 SERTA RELEVANSINYA SEBAGAI BAHAN AJAR TEKS ULASAN DI SMP DAN SMA
}

\author{
Meilani Wahyu Pangestika, Ani Rakhmawati, Raheni Suhita \\ Universitas Sebelas Maret \\ Surel: meilaniwahyu@student.uns.ac.id
}

\begin{abstract}
Abstrak: Penelitian ini bertujuan untuk mendeskripsikan dan menjelaskan: (1) struktur wacana rubrik resensi buku pada surat kabar Solopos edisi Januari-Desember 2017; (2) aspek tekstual rubrik resensi buku; (3) aspek kontekstual rubrik resensi buku; dan (4) relevansi rubrik resensi buku pada surat kabar Solopos edisi Januari-Desember 2017 sebagai bahan ajar teks ulasan di SMP dan SMA. Penelitian ini merupakan penelitian deskriptif kualitatif. Hasil penelitian ini menunjukkan bahwa: (1) struktur wacana rubrik resensi buku terdiri paragraf pembuka, paragraf penghubung atau isi, dan paragraf penutup; (2) aspek tekstual yang mendukung keutuhan wacana terdiri dari topik wacana, kohesi dan koherensi, serta bentuk kata; (3) aspek kontekstual pada wacana dapat dapat dipahami melalui empat prinsip penafsiran, yaitu: penafsiran personal, penafsiran lokasional, penafsiran temporal, dan prinsip analogi; dan (4) rubrik resensi buku pada surat kabar Solopos edisi bulan Januari-Desember 2017 dapat dijadikan bahan ajar materi teks ulasan di SMP dan SMA.
\end{abstract}

Kata Kunci: analisis wacana, resensi, teks ulasan

\section{DISCOURSE ANALYSIS OF THE RUBRIC RESENSE ON THE NEWSPAPER OF SOLOPOS EDITION JANUARY-DECEMBER 2017 AND ITS RELEVANCE AS LEARNING MATERIAL OF REVIEW TEXT IN JUNIOR HIGH SCHOOL AND SENIOR HIGH SCHOOL}

\begin{abstract}
Abstrack: This research aimed at describing and explaining about (1) the discourse structure of review text on book review columns in Solopos Newspaper January-December 2017 edition; (2) the textual aspects of book review; (3) the contextual aspects of book review; (4) the relevance of book review columns in Solopos Newspaper January-December 2017 edition as the teaching materials of review text in Secondary Junior High Schools and in Secondary Senior High Schools. The type of this research is qualitative descriptive. The results of this research indicated that (1) the discourse structure of review text on book review columns included opening paragraph, contacting paragraph or content, and closing paragraph; (2) textual aspects supporting the completeness of book review were the topic of discourse, aspects of cohesion and coherence, and forms of words; (3) the contextual aspects on book review could be understood through four interpretive principles, namely: the principle of personal interpretation, the principle of local interpretation, the principle of temporal interpretation, and the principle of analogy; and (4) the results of this research also indicated that book review columns in Solopos Newspaper January-December 2017 edition could be used as the teaching materials of review text in Junior High Schools and Senior High Schools.
\end{abstract}

Keywords: discourse analysis, book review, text review

BASASTRA Jurnal Bahasa, Sastra, dan Pengajarannya

Volume 6 Nomor 2, Oktober 2018, ISSN 2302-6405 


\section{PENDAHULUAN}

Kurikulum 2013 merupakan perbaikan dan penyempurnaan dari kurikulum sebelumnya, yaitu kurikulum 2006 atau KTSP (Kurikulum Tingkat Satuan Pendidikan). Kurikulum 2013 dirancang untuk menyongsong model pembelajaran abad ke-21, yang di dalamnya terdapat pergeseran dari siswa diberitahu menjadi siswa mencari tahu dari berbagai sumber belajar melampaui batas pendidik dan satuan pendidikan (Jamilah, 2017). Pada kurikulum 2013, pembelajaran Bahasa Indonesia diorientasikan pada pembelajaran berbasis teks. Menurut Mahsun (dalam Meza, Mustofa, \& Karomani, 2015) teks wujudnya dapat berupa bahasa yang dituturkan atau dituliskan, atau juga bentuk-bentuk sarana lain yang digunakan untuk menyatakan apa saja yang dipikirkan Sebagaimana yang dikemukakan Slamet (2007: 6), bahwa pengajaran bahasa Indonesia adalah pengajaran keterampilan berbahasa bukan pengajaran tentang kebahasaan. Teori-teori bahasa hanya sebagai pendukung atau penjelas dalam konteks, yaitu yang berkaitan dengan keterampilan tertentu yang tengah diajarkan..

Salah satu teks yang dipelajari pada jenjang Sekolah Menengah Pertama dan Sekolah Menengah Atas adalah teks ulasan. Teks ulasan merupakan teks yang di dalamnya berisi identitas, kelebihan dan kekurangan, tanggapan atau tinjauan, serta kritik dan saran mengenai suatu karya (puisi, cerpen, buku, film, drama, dan lain sebagainya). Pada dasarnya teks ulasan merupakan suatu teks yang dihasilkan dari sebuah analisis terhadap suatu karya. Belajar mengenai teks ulasan sesungguhnya memiliki banyak manfaat bagi siswa, yaitu: (1) membantu siswa untuk belajar berpikir kritis, karena di dalam teks ulasan siswa perlu menganalisis dan menilai sebuah karya; (2) menambah pengetahuan siswa mengenai buku-buku baru yang mungkin saja belum diketahui siswa; (3) siswa dapat berlatih untuk mengungkapkan ide dan gagasannya yang dituangkan dalam bentuk teks ulasan; dan lain sebagainya. Odoom (2014) menyatakan bahwa ulasan buku tidak hanya sekedar ringkasan atau pernyataan pujian belaka terhadap suatu buku atau karya, melainkan komentar yang bersifat evaluatif di mana ulasan buku itu menunjukkan pengetahun yang dimiliki oleh resentator mengenai buku tersebut.

Pembelajaran berbasis teks memiliki tujuan agar siswa dapat memahami ilmu pengetahuan melalui teks yang disajikan sesuai dengan tujuan-tujuan tertentu. Dengan demikian, analisis yang mendalam mengenai sebuah teks tentunya penting dilakukan untuk dapat memahami teks tersebut. Salah satu kajian yang dapat dipakai untuk mengkaji sebuah teks adalah analisis wacana. Stubbs (dalam Badara, 2013: 18) mengatakan bahwa analisis wacana merupakan suatu kajian yang meneliti atau menganalisis bahasa yang digunakan secara alamiah, baik dalam bentuk lisan maupun tulisan. Analisis wacana dapat diartikan sebagai studi tentang struktur pesan dalam komunikasi. Analisis wacana dapat mengaplikasikan semua unsur kebahasaan (Wijana dan Rohmadi, 2011: 72). Namun demikian, analisis wacana teks tidak dapat meninggalkan analisis konteks. Hal tersebut dikarenakan konteks memiliki peran penting untuk mengungkap makna yang ada dalam teks.

Dalam konteks analisis wacana, kata atau kalimat yang berposisi sebagai wacana disyaratkan memiliki kelengkapan makna, informasi, dan konteks tuturan yang jelas dan mendukung (Mulyana, 2005: 8). Terdapat dua aspek yang dikaji dalam analisis wacana yaitu aspek tekstual dan kontekstual. Analisis wacana tekstual adalah analisis yang dilakukan dengan melihat suatu wacana berdasarkan teksnya. Analisis wacana kontekstual merupakan analisis 
wacana yang bertumpu pada teks yang dikaji berdasarkan konteks eksternal yang melingkupinya, baik konteks situasi maupun konteks kultural (budaya). Lebih lanjut Mahsun (2014: 39) juga menyatakan bahwa dalam pembelajaran bahasa ada dua komponen yang harus dipelajarai, yaitu masalah makna dan bentuk. Oleh karena itu, kajian wacana tentunya mencakup aspek yang sangat luas sehingga menarik untuk diteliti lebih lanjut.

Penelitian ini mengkaji rubrik resensi buku pada surat kabar Solopos edisi JanuariDesember 2017 dengan kajian analisis wacana. Analisis wacana yang dilakukan yaitu secara tekstual dan kontekstual. Analisis wacana secara tekstual dilakukan dengan menganalisis aspek struktur wacana, topik wacana, kohhesi dan koherensi, dan bentuk kata. Sedangkan analisis wacana secara kontekstual dilakukan dengan menggunakan empat prinsip yaitu prinsip penafsiran personal, prinsip penafsiran lokasional, prinsip penafsiran temporal, dan prinsip analogi.

Resensi adalah jenis karya tulis yang berisi hasil penimbangan, pengulasan, atau penilaian mengenai sebuah karya puisi, novel, buku, film, drama, dan lain sebagainya. Dalam membicarakan atau mengulas sebuah buku secara tertulis tentu saja di dalam isi tulisan tersebut terdapat bagian tentang menilai kelebihan dan kekurangan buku itu, menarik tidaknya topik buku, ungkapan kritik dan saran terhadap buku, serta kelayakan buku tersebut untuk dibaca. Tujuan dari resensi tersebut ialah memberi pertimbangan dan penilaian secara objektif, sehingga masyarakat mengetahui apakah buku yang diulas tersebut patut dibaca atau tidak. Sistematika penulisan resensi terdiri dari bagian pendahuluan, isi, dan penutup (Kusmana, 2014: 30).

Berdasarkan uraian yang telah dijabarkan tersebut, maka judul penelitian ini adalah “Analisis Wacana Rubrik Resensi
Buku pada Surat Kabar Solopos edisi Januari-Desember 2017 serta Relevansinya sebagai Bahan Ajar Teks Ulasan di SMP dan SMA”.

\section{METODE PENELITIAN}

Jenis penelitian ini adalah deskriptif kualitatif. Menurut Sugiyono (2016: 1) metode penelitian kualitatif adalah metode penelitian yang digunakan untuk meneliti pada kondisi objek alamiah, dimana peneliti adalah sebagai instrumen kunci, teknik pengumpulan data dilakukan secara trianggulasi (gabungan), analisis data bersifat induktif, dan hasil penelitian kualitatif lebih menekankan makna dari pada generalisasi.

Data dan sumber data yang digunakan pada penelitian ini adalah dokumen dan informan. Dokumen yang diteliti berasal dari rubrik resensi buku pada surat kabar Solopos edisi Januari-Desember 2017. Adapun informan yang digunakan pada penelitian ini adalah guru Bahasa Indonesia. Teknik sampling yang digunakan dalam penelitian ini adalah purposive sampling. Teknik pengumpulan data yang digunakan dalam penelitian ini adalah teknik analisis dokumen, catat, dan wawancara. Teknik uji validitas data yang digunakan yaitu teknik triangulasi sumber data dan triangulasi teori. Penelitian ini menggunakan analisis data menurut Miles \& Huberman yaitu analisis interaktif yang meliputi pengumpulan data, reduksi data, penyajian data, dan penarikan kesimpulan.

\section{HASIL DAN PEMBAHASAN \\ Analisis Struktur Wacana Rubrik Resensi pada Surat Kabar Solopos edisi Januari- Desember 2017}

Secara keseluruhan, dari duabelas wacana resensi buku yang dianalisis, ditemukan pola struktur wacana yang sama. Pola struktur wacana tersebut terdiri dari paragraf pembuka, paragraf penghubung 
atau isi, dan paragraf penutup. Hal tersebut sejalan dengan pendapat yang dikemukakan oleh Rohmadi dan Nasucha (2010: 14) bahwa setiap wacana tulis harus memiliki struktur wacana yang meliputi pembukaan yang disebut paragraf pembuka, isi yang disebut paragraf penghubung, dan kesimpulan yang disebut paragraf penutup. Ketiga struktur tersebut harus ada dalam setiap karangan. Apabila salah satu dari ketiga unsur itu tidak ada, maka karangan itu dianggap tidak lengkap. Struktur wacana pada rubrik resensi buku surat kabar Solopos edisi Januari-Desember 2017 dilengkapi dengan adanya judul resensi dan identitas buku.

\section{Analisis Wacana Tekstual Rubrik Resensi pada Surat Kabar Solopos edisi Januari- Desember 2017}

Pada analisis wacana secara tekstual terdapat beberapa aspek yang akan dianalisis, yaitu terdiri dari topik wacana, kohesi dan koherensi, serta bentuk kata. Berikut adalah penjelasan dari masingmasing aspek kontekstual yang dianalisis.

\section{Topik Wacana}

Tiap-tiap wacana resensi buku yang dianalisis sudah memiliki topik wacana yang jelas. Hal tersebut sejalan dengan pendapat Oka dan Suparno dalam bukunya Linguistik Umum (1994), ada sejumlah persyaratan yang menentukan terbentuknya wacana, yaitu topik, tuturan pengungkap topik, serta kohesi dan koherensi. Salah satu persyaratan yang disampaikan yaitu topik. Topik mengacu pada hal yang dibicarakan dalam wacana. Secara mendasar topik diartikan sebagai pokok pembicaraan. Dalam wacana, topik menjadi ukuran kejelasan suatu wacana. Topik yang jelas akan menyebabkan struktur dan isi wacana menjadi jelas pula. Sebaliknya, topik yang tidak jelas, atau bahkan tulisan tanpa topik, menyebabkan tulisan tersebut menjadi kabur dan sulit dimengerti maksudnya.

\section{Kohesi dan Koherensi}

Aspek kohesi masih dibagi lagi menjadi dua jenis yaitu aspek leksikal (pengacuan, penyulihan, pelesapan, konjungsi) dan aspek gramatikal (repetisi, sinonimi, antonimi, kolokasi, ekuivalensi).

\section{Kohesi Gramatikal}

\section{Pengacuan}

Ditemukan 188 data pengacuan persona di dalam duabelas resensi yang dianalisis. Contoh data pengacuan persona di antara lain

(a) tantangan Muhammdiyah hari ini tentu berbeda dengan era awal berdirinya perserikatan itu. (DT1/SP/21Jan17).

(b) buku yang berjudul "Penimba Bahasa" itu berisi lima esai yang mengupas laku berbahasa kita hari ini. (DT4/SP/16Apr17).

(c) semua perjalanan itu telah dirasakan dan dicatat Frank Foer. Ia menampilkan dunia sepak bola yang tidak mirip mulut para pengkhotbah sepak bola. (DT12/SP/31Des17).

(d) Maka tak heran, dewasa ini berbagai lembaga pendidikan Muhammadiyah terus tumbuh, berkembang, dan tersebar di seantero Nusantara. (DT10/SP/29Okt17).

(e) Ilmu kedokteran yang dimiliki penulis bisa dinikmati seperti novel-novelnya.

Pada kutipan (a) terdapat pronominal persona ketiga tunggal bentuk terikat lekat kanan-nya, pada kata berdirinya. Kata-nya tersebut mengacu pada unsur lain yang berada di dalam wacana yang disebutkan sebelumnya, yaitu Muhammadiyah. Penggunaan kata kita dalam kutipan (b) mengacu pada unsur lain di luar teks yaitu penulis resensi dan pembaca. Kata kita termasuk dalam pengacuan persona pertama jamak bebas. Tuturan tersebut merupakan pengacuan eksofora karena acuannya berada di luar teks. Pengacuan persona ketiga tunggal berturut-turut terdapat dalam kutipan 
(c). Pengacuan tersebut ditandai dengan adanya kata $\boldsymbol{i} \boldsymbol{a}$ yang mengacu pada unsur yang sudah disebutkan sebelumnya. Kemudian pada kutipan (d) terdapat pengacuan demonstratif temporal yang ditandai dengan adanya frasa dewasa ini. Pada kutipan (e) terdapat kata seperti yang termasuk dalam pengacuan komparatif. Pengacuan komparatif atau perbandingan adalah satu jenis kohesi gramatikal yang bersifat membandingkan dua hal atau lebih yang memiliki kemiripan.

\section{Penyulihan (substitusi)}

Ditemukan 24 data penyulihan di dalam duabelas resensi yang dianalisis. Contoh data penyulihan di antara lain:

(a) Sebagaimana disampaikan dalam pengantar $\boldsymbol{b u k u}$ ini, secara ringkas karya ini memaparkan akhlak dan perangai para sufi yang selalu berpegang teguh kepada ajaran Alquran dan sunah. (DT5/SP/28Mei1

(b) Oleh karena itu, dua pakar pemasaran kelas dunia Philip Kotler dan Hermawan Kartajaya kembali berkolaborasi untuk melnasir buku Marketing4.0: Moving from Traditional to Digital. Kali ini, mereja juga menggandeng ahli strategi pemasaran Iwan Setiawan. (DT7/SP/16Jul17)

Pada kutipan (a) dan kutipan (b) ditemukan adanya subtitusi yang termasuk ke dalam substitusi nominal. Subtitusi nominal adalah penggantian satuan lingual yang berkategori nomina (kata benda) dengan satuan lain yang juga berkategor nomina. Pada kutipan a) kata buku disubstitusikan dengan kata karya, dan pada kutipan b) kata pakar disubstitusikan dengan kata ahli.

\section{Pelesapan (elipsis)}

Ditemukan 23 data pelesapan di dalam duabelas resensi yang dianalisis. Contoh data pelesapan di antara lain:

(a) Secara umum, melalui buku ini, pembaca bisa mendapatkan empat pembelajaran penting, yaitu menemukan peraturan baru dalam dunia pemasaran, bagaimana agar bisa menonjol dan menciptakan momentum yang 'wow', bagaimana membangun basis konsumen yang vokal dan loyal, serta bagaimana mengetahui apa yang akan membentuk preferensi konsumen pada masa mendatang. (DT7/SP/16Jul17)

Kutipan (a) menunjukkan adanya pelesapan yang terjadi pada kata pembelajaran. Pelesapan tersebut dilakukan sebanyak empat kali pada tuturan berikutnya. Peristiwa pelesapan pada tuturan (a) dapat dipresentasikan menjadi a1), dan apabila tuturan itu kembali dituliskan dalam bentuk yang lengkap tanpa adanya pelesapan, maka akan tampak seperti a2) berikut:

a1) Secara umum, melalui buku ini, pembaca bisa mendapatkan empat pembelajaran penting, yaitu $\varnothing$ menemukan peraturan baru dalam dunia pemasaran, $\varnothing$ bagaimana agar bisa menonjol dan menciptakan momentum yang 'wow', Ø bagaimana membangun basis konsumen yang vokal dan loyal, serta $\varnothing$ bagaimana mengetahui apa yang akan membentuk preferensi konsumen pada masa mendatang.

a2) Secara umum, melalui buku ini, pembaca bisa mendapatkan empat pembelajaran penting, yaitu pembelajaran menemukan peraturan baru dalam dunia pemasaran, pembelajaran bagaimana agar bisa menonjol dan menciptakan momentum yang 'wow', 
pembelajaran bagaimana membangun basis konsumen yang vokal dan loyal, serta pembelajaran bagaimana mengetahui apa yang akan membentuk preferensi konsumen pada masa mendatang.

\section{Konjungsi}

Terdapat tiga jenis konjungsi yang ditemukan yaitu konjungsi koordinatif, konjungsi subordinatif, dan konjungsi korelatif. Ditemukan 351 data konjungsi di dalam duabelas resensi yang dianalisis. Berikut merupakan contoh data perangkaian (konjungsi) yang ditemukan:

(a) Muhammadiyah terus berbenah dan menjadi pelopor gerakan tajdid (pembaruan) di Indonesia. (DT1/SP/29Jan17)

(b) Ini terjadi karena memang di antara kedua istilah tersebut bisa jadi memiliki makna yang bisa jadi memang sama, walaupun sebenarnya memiliki (DT6/SP/18Jun17)

(c) Mohamad Ali sebagai cendekiawan aktivis Muhammadiyah tidak hanya menjelaskan fenomena historis pendidikan Muhammadiyah, tetapi juga mengupas filososfi pendidikan yang bergema di pikiran K.H. Ahmad Dahlan. (DT10/SP/29Okt17)

(d) Frank Foer jurnalis politik majalah New Republic meminta izin cuti selama delapan bulan untuk melakukan riset panjang tentang sepak bola. (DT12/SP/31Des17)

Pada kutipan (a) terdapat kata dan yang termasuk dalam konjungsi koordinatif yang menandai adanya hubungan penambahan. Pada kutipan b) terdapat subordinatif sebab yang ditandai dengan munculnya kata karena. Dalam kutipan (b) juga ditemukan adanya subordinatif kohesif yang ditandai dengan kata walaupun. Konjungsi subordinatif pembandingan terdapat pada kutipan c) yang ditandai dengan adanya kata sebagai. Konjungsi subordinatif waktu ditandai dengan kata selama nampak pada kutipan (d). Kemudian yang terakhir adalah konjungsi korelatif. Konjungsi korelatif adalah konjungsi yang menghubungkan dua bagian yang berstatus sama. Bentuk dari konjungsi korelatif yang ditemukan terdapat pada kutipan (c) yaitu ditandai dengan tidak hanya...tetapi juga.

Dari hasil analisis data tersebut, peneliti menemukan bahwa data pengacuan yang paling dominan dari kedua belas resensi tersebut adalah data pengacuan persona ketiga tunggal. Hal ini dapat dilihat dengan seringnya pemakaian kata ganti orang ketiga tunggal baik bentuk bebas dia, ia, dan bentuk lekat kanan -nya. Hal tersebut sejalan dengan penelitian Andriyani (2015) Analisis Wacana Tekstual dan Kontekstual Kumpulan Cerpen Sampah Bulan Desember Karya Hamsad Rangkuti serta Relevansinya sebagai Bahan Ajar di Sekolah Menengah Pertama. Dalam penelitian tersebut juga disimpulkan bahwa penggunaan pengacuan persona ketiga tunggal paling banyak digunakan dibandingkan dengan pengacuan persona lainnya. Kemudian berdasarkan keempat aspek yang dikaji tersebut, aspek konjungsi merupakan aspek yang paling dominan atau paling banyak ditemukan. Hal tersebut sejalan dengan penelitian yang dilakukan oleh Farida (2011) Rubrik Resensi pada Harian Umum Solopos: Kajian Wacana Tekstual dan Kontekstual (Edisi Bulan Januari-Maret 2011). Dari penelitian tersebut disimpulkan bahwa aspek konjungsi yang paling sering muncul dalam wacana resensi yaitu aspek konjungsi subordinatif. Hal tersebut dikarenakan konjungsi subordinatif masih terbagi ke dalam beberapa jenis sehingga jumlahnya lebih banyak. 


\section{Kohesi Leksikal \\ Repetisi}

Ditemukan 44 data repetisi di dalam duabelas resensi yang dianalisis. Berikut merupakan contoh data repetisi yang ditemukan:

(a) Muhammadiyah sedang dan telah menyusun beberapa fikih baru yang mencerminkan watak kosmopolitannya. Di antaranya adalah Fikih Air, Fikih Kebencanaan, Fikih Jurnalistik, dan Fikih Difabel. (DT1/SP/19Jan17)

(b) Taufiq bukan sekadar mendaur ulang tulisan opini yang pernah dimuat di sejumlah koran, namun menambahkan sejumlah teori, latar belakang, serta aspek-aspek hukum yang menyebabkan terjadinya kejahatan terorisme.

(DT2/SP/19Feb17)

(c) Bahkan pembunuhan, pelanggaran yang beraroma kriminalitas turut membawa cerita ke dalam tatanan cerita yang begitu terkesan tragis. Pembunuhan yang mungkin tak pernah disangka para pembaca sebelumnya. (DT3/SP/26Mar17)

Pada kutipan (a) terdapat pengulangan bentuk satuan lingual kata fikih sebanyak lima kali guna menekankan pentingnya kata tersebut dalam konteks tuturan. Repetisi yang terjadi dalam kutipan (b) termasuk dalam repetisi epizeuksis, yaitu pengulangan satuan lingual (kata) yang dipentingkan beberapa kali secara berturut-turut (Saddhono, 2009: 44). Repetisi yang bersifat tautotes yaitu pengulangan satuan lingual (sebuah kata) beberapa kali dalam sebuah konstruksi nampak terjadi dalam kutipan (b). Pada kutipan (c) terdapat pengulangan kata pembunuhan sebanyak dua kali. Repetisi yang terjadi pada kutipan (c) termasuk dalam repetisi anafora karena pengulangan satuan lingual berupa kata terjadi pada kalimat berikutnya.
Sinonimi

(a) Kisah cinta sepasang kekasih yang dilamun asmara, namun begitu banyak sekali rintangan yang menghalangi mereka. (DT3/SP/26Mar17)

(b) Mengingat hidup pada era digital sekarang ini kita harus mampu beradaptasi dengan perubahanperubahan sebagai akibat cepatnya perkembangan teknologi yang berdampak kepada gaya hidup, sikap, perilaku, pengetahuan, dan bahkan hampir di semua aspek kehidupan. (DT6/SP/18Jun17)

Pada kutipan (a) terdapat kata cinta dan asmara, dimana kedua kata tersebut memiliki makna yang sama. Asmara (menurut KBBI) memiliki arti perasaan senang kepada lain jenis (kelamin); (rasa) cinta. Kutipan (b) terdapat dua pasang kata yang saling bersinonim atau memiliki makna yang sama, yang pertama yaitu kata akibat dan berdampak, kemudian yang kedua yaitu kata sikap dan perilaku. Kata akibat dan dampak memiliki makna yang sama, begitu pula kata sikap dan perilaku. Oleh karena itu, kedua pasang kata tersebut saling bersinonim.

\section{Antonimi}

(a) Meski "marah", esai Naimatur terasa sedap dibaca lantaran keluwesan serta kepiawaiannya menyisipkan kelakar, selain juga karena sarat informasi baru yang bersumber dari koran/majalah lawas. (DT4/SP/16Apr17)

(b) Cepat atau lambat, implementasi teknologi akan diterapkan di sekitar kita. (DT6/SP/18Jun17)

Kedua kata baru dan lawas pada kutipan (a) merupakan antonimi mutlak. Kedua kata tersebut beroposisi mutlak karena tidak ada kata agak baru atau agak lawas. Oposisi mutlak adalah pertentangan 
makna secara mutlak. Kata cepat dan lambat pada kutipan (b) termasuk ke dalam jenis antonim dengan oposisi kutub. Kedua kata tersebut beroposisi kutub karena terdapat gradasi diantara keduanya yaitu: agak cepat, cepat, dan agak lambat, lambat.

\section{Kolokasi}

(a) Kisah cinta sepasang kekasih yang dilamun asmara, namun begitu banyak sekali rintangan yang menghalangi mereka. Cinta yang tulus selalu ada rintangan halangan untuk sekadar mencapai kata cinta suci itu sendiri. (DT3/SP/26Mar17)

(b) Buku berjudul Penimba Bahasa itu berisi lima esai yang mengupas laku berbahasa kita hari ini. Mulai dari penggusuran bahasa Indonesia oleh bahasa asing, hingga bahasa slang di dunia siber. (DT4/SP/16Apr17)

Data (a) tampak pemakaian kata cinta, asmara, dan tulus dimana kata-kata tersebut merupakan kata yang biasa dipakai dalam domain perasaan atau percintaan. Kata berbahasa, bahasa Indonesia, bahasa asing, dan bahasa slang yang dipakai pada data (b) di atas merupakan kata-kata yang dipakai secara berdampingan untuk mendukung kepaduan wacana tersebut. Kata-kata tersebut biasa dipakai dalam domain bahasa atau kebahasaan.

\section{Ekuivalensi}

Ekuivalensi merupakan sebuah kata yang dibentuk dari hasil proses afiksasi dari morfem yang sama dan menunjukkan adanya hubungan kesepadanan.

(a) Konflik di dalamnya memang sudah sering diangkat penulis di novelnya yang lain, dan mungkin membuat novel ini agaknya "terasa seperti yang lalu-lalu". Namun lantaran cara menulis yang memikat, serta penyuguhan cerita yang menarik, Mira W. selalu melahirkan rasa dan emosi yang selalu baru bagi pembaca. (DT3/SP/26Mar17)

(b) Buku ini terbit dengan kebaruan dan keunikannya tersendiri. Sebab, selama ini penelitian tentang pemikiran pembaharuan K.H. Ahmad Dahlan pada umumnya berhenti pada penemuan konsep bahwa pemikiran pendidikan keagamaannya dipengaruhi oleh tokoh-tokoh Timur Tengah. (DT10/SP/29Okt17)

Pada data a) terdapat kata penulis dan menulis yang merupakan kata hasil afiksasi dari morfem yang sama yaitu tulis. Kata kebaruan dan pembaharuan pada data b) merupakan kata hasil afiksasi dari morfem asal yang sama sehingga menunjukkan adanya kesepadanan. Kedua kata tersebut berasal dari bentuk kata baru.

Pada penelitian ini, repetisi merupakan aspek leksikal yang paling banyak ditemukan. Hal tersebut sejalan dengan penelitian yang dilakukan oleh Farida (2011) Rubrik Resensi pada Harian Umum Solopos: Kajian Wacana Tekstual dan Kontekstual (Edisi Bulan Januari-Maret 2011). Dari penelitian tersebut disimpulkan bahwa aspek leksikal berupa repetisi mendominasi penggunaannya dalam wacana resensi tersebut. Koherensi mengandung makna pertalian, HS Wahyudi (dalam Mulyana, 2005: 30) berpendapat bahwa koherensi ialah keterkaitan antara bagian yang satu dengan bagian yang lainnya, sehingga kalimat memiliki kesatuan makna yang utuh. Secara keseluruhan pertalian atau hubungan makna yang terdapat dalam wacana resensi surat kabar Solopos edisi Januari-Desember 2017 cukup jelas, sehingga pembaca dapat memahami wacana tersebut dengan mudah. Mulyana (2005: 31) menambahkan bahwa koherensi dapat terjadi secara implisit (terselubung) karena berkaitan dengan bidang makna yang memerlukan interpretasi. Aspek kohesi dan koherensi pada data wacana resensi yang 
dianalisis saling berkaitan satu sama lain guna mendukung keutuhan wacana tersebut.

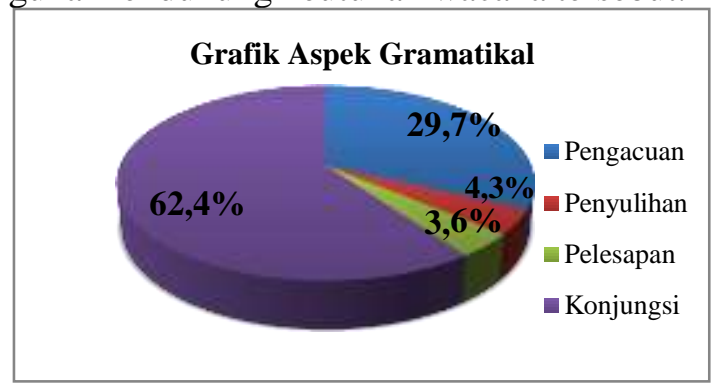

Grafik 1. Analisis Aspek Gramatikal Rubrik Resensi Surat Kabar Solopos edisi JanuariDesember 2017

Berdasarkan grafik tersebut, dapat diketahui bahwa pendukung kepaduan wacana dari aspek gramatikal terdiri dari empat unsur yaitu pengacuan, penyulihan, pelesapan, dan konjungsi. Unsur yang paling dominan atau paling banyak ditemukan adalah konjungsi (perangkaian).

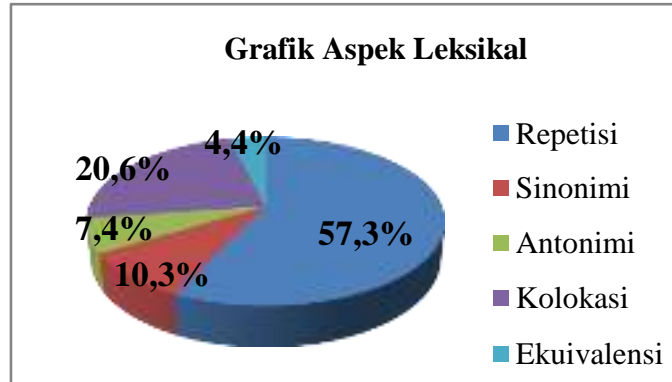

Grafik 2. Analisis Aspek Leksikal Rubrik Resensi Surat Kabar Solopos Edisi JanuariDesember 2017

Berdasarkan grafik tersebut, dapat diketahui bahwa pendukung kepaduan wacana dari aspek leksikal terdiri dari lima unsur yaitu repetisi, sinonimi, antonimi, kolokasi, dan ekuivalensi.. Unsur yang paling dominan atau paling banyak ditemukan adalah repetisi (pengulangan).

\section{Bentuk Kata}

Berdasarkan dua belas resensi yang telah dianalisis, bentuk kata yang ditemukan pada data-data tersebut berupa kata ganti, kata penghubung (konjungsi), kata sinonim, dan kata antonim. Klasifikasi atau penggolongan kata itu memang perlu, sebab besar manfaatnya, baik secara teoretis dalam studi semantik, maupun secara praktis dalam berlatih keterampilan berbahasa. Chaer (2012: 169) juga mengatakan, dengan mengenal kelas sebuah kata, yang dapat kita identifikasikan dari ciri-cirinya, kita dapat memprediksi penggunaan atau pendistribusian kata itu di dalam ujaran, sebab hanya kata-kata yang berciri atau beridentifikasi yang sama saja yang dapat menduduki suatu fungsi atau suatu distribusi di dalam kalimat.

\section{Analisis Wacana Kontekstual Rubrik Resensi pada Surat Kabar Solopos edisi Januari-Desember 2017}

Pada analisis wacana secara kontekstual, terdapat empat prinsip yang digunakan untuk dapat memahami aspekaspek kontekstual yang terdapat dalam sebuah wacana. Empat prinsip tersebut terdiri dari prinsip penafsiran personal, prinsip penafsiran lokasional, prinsip penafsiran temporal, dan prinsip analogi.

\section{Prinsip Penafsiran Personal}

Prinsip penafsiran personal berkaitan dengan siapa sesungguhnya yang menjadi partisipan di dalam suatu wacana. Dalam hal ini, siapa penutur dan siapa mitra tutur sangat menentukan makna sebuah tuturan. Halliday dan Hasan (dalam Sumarlam, 2008: 48) menyebut penutur dan mitra tutur atau partisipan dengan istilah "pelibat wacana". Wacana resensi pada dasarnya merupakan sebuah wacana provokatif yang sifatnya menginformasikan sekaligus membujuk serta bersifat monolog. Oleh karena itu, di dalam wacana resensi terjadi komunikasi satu arah yaitu antara penutur (penulis resensi) dengan mitra tutur (pembaca). 


\section{Prinsip Penafsiran Lokasional}

Prinsip ini berkenaan dengan penafsiran tempat atau lokasi terjadinya suatu situasi (keadaan, peristiwa, dan proses) dalam rangka memahami wacana (Sumarlam, 2008: 49). Pada penelitian ini, wacana yang dianalisis merupakan wacana resensi buku. Resensi buku menurut Kusmana (2014: 29) merupakan kegiatan membahas atau membicarakan kualitas suatu buku atau suatu pertunjukkan fim, drama, seni pentas, atau teater, yang disajikan secara tertulis atau lisan dalam bentuk pembicaraan. Wacana resensi buku yang dianalisis pada penelitian ini yaitu dalam bentuk tulis, yang diambil dari surat kabar Solopos. Oleh karena itu, tempat dimana berlangsungnya wacana resensi tidak dapat dianalisis.

\section{Prinsip Penafsiran Temporal}

Prinsip penafsiran temporal berkaitan dengan pemahaman mengenai waktu (Sumarlam, 2006: 49). Berdasarkan konteksnya kita dapat menafsirkan kapan atau berapa lama waktu terjadinya suatu situasi (peristiwa, keadaan, proses). Dalam wacana resensi analisis mengenai waktu terjadinya wacana hanya dapat dianalisis secara implisit. Makna implisit merupakan makna yang tidak dapat ditangkap langsung oleh pembaca.

(a) Kiranya, lima esai itu menjadi potret kekinian kondisi bahasa Indonesia dan penuturnya di masa sekarang. (DT4/SP/16Apr17)

(b) Singkat kata, buku ini akan memberi Anda pemahaman kompleks terkait dengan perkembangan tekonologi komunikasi sejak zaman belum ditemukannya internet hingga soal ciri-ciri masyarakat informasi, serta betapa dahsyatnya kekuatan masyarakat maya di era siber media sekarang ini. (DT6/SP/18Jun17)

(c) Memasuki bulan Agustus sebagai bulan penting dalam sejarah
Indonesia, kita pantas membaca esai berjudul Wajah Perempuan dalam Kemerdekaan. (DT8/SP/20Ags17)

Terdapat makna implisit yang terkandung pada tiga ujaran di atas. Pada data (a) kata kekinian dan masa sekarang menunjukkan bahwa wacana resensi tersebut terjadi dalam jangka waktu yang cukup lama. Tidak dapat dipastikan kapan wacana resensi tersebut terjadi. Pada data (b) terdapat ujaran era siber media sekarang ini, dari ujaran tersebut pembaca dapat memahami waktu terjadinya wacana resensi tersebut yaitu pada masa kini ketika perkembangan teknologi semakin pesat. Namun, sama dengan data (a) tidak dapat dipastikan kapan wacana resensi tersebut terjadi. Kemudian pada data (c) pembaca dapat lebih mudah memahami makna implisit mengenai kapan terjadinya wacana resensi tersebut secara lebih karena terdapat petunjuk yaitu pada ujaran memasuki bulan Agustus.

\section{Prinsip Analogi}

Prinsip analogi digunakan sebagai dasar, baik oleh penutur maupun mitra tutur untuk memahami makna dan mengidentifikasi maksud dari (bagian atau keseluruhan) sebuah wacana (Sumarlam, 2006: 50). Resensi merupakan kegiatan membahas atau membicarakan kualitas suatu buku atau suatu pertunjukkan fim, drama, seni pentas, atau teater, yang disajikan secara tertulis atau lisan dalam bentuk pembicaraan. Makna, maksud, atau tujuan dari penulisan resensi buku adalah untuk memberi pertimbangan dan penilaian secara objektif, sehingga masyarakat mengetahui apakah buku yang diulas tersebut patut dibaca atau tidak. Maksud dari penulisan resensi buku dapat dianalisis dengan prinsip analogi.

(a) Akhirnya buku ini cukup layak sebagai bacaan dan referensi terkait dengan isu terorisme khususnya di Indonesia. (DT2/SP/19Feb17) 
(b) Buku ini akan memandu kita tentang cara meraih rahmat Tuhan untuk membuka pintu surga. Selamat membaca dan menyelami lautan inspirasi di dalamnya. (DT5/SP/28Mei17)

(c) Melalui buku yang sangat menginspirasi ini, pembaca dapat belajar banyak tentang arti keihklasan berbagi dan melayani sesama di tengah segala ketebatasan. (DT11/SP/12Nov17)

Berdasarkan data-data yang telah disebutkan di atas, dapat dipahami bahwa sesungguhnya maksud dan tujuan dari penulisan resensi adalah untuk memberikan informasi kepada pembaca mengenai sebuah buku.

\section{Relevansi Rubrik Resensi Buku sebagai Bahan Ajar Teks Ulasan di SMP}

Dari keduabelas resensi buku dari surat kabar Solopos edisi Januari-Desember 2017 yang menjadi objek penelitian dalam skripsi ini ada yang cocok dan ada yang kurang cocok untuk dijadikan bahan ajar bahasa Indonesia di Sekolah Menengah Pertama. Widodo \& Jasmadi (dalam Lestari, 2013: 1) menjelaskan bahan ajar adalah seperangkat sarana atau alat pembelajaran yang berisikan materi pembelajaran, metode, batasan-batasan, dan cara mengevaluasi yang didesain secara sistematis dan menarik dalam rangka mencapai tujuan yang diharapkan, yaitu mencapai kompetensi atau subkompetensi dengan segala kompleksitasnya.

Dilihat dari strukturnya, semua resensi yang dianalisis sudah memenuhi kriteria yaitu terdiri dari judul resensi, identitas buku yang diresensi, pendahuluan, isi resensi, dan penutup/kesimpulan. Hal tersebut sudah sesuai dengan teori struktur teks ulasan yang diajarkan di SMP kelas VIII. Kemudian dari segi kebahasaan, bahasa yang dipakai dalam resensi-resensi tersebut cukup mudah dipahami siswa sehingga cocok untuk dijadikan bahan ajar.

Dilihat dari kompetensi dasar yang terdapat di dalam kurikulum 2013, resensi buku ini sesuai jika digunakan sebagai bahan ajar siswa SMP kelas VIII. Kompetensi dasar yang berkaitan dengan penelitian ini terdapat pada kompetensi dasar 3.11 yaitu mengidentifikasi informasi pada teks ulasan tentang kualitas karya (film, cerpen, puisi, novel, dan karya seni daerah) yang dibaca atau diperdengarkan, dan 3.12 yaitu menelaah struktur dan kebahasaan teks ulasan (film, cerpen, puisi, novel, dan karya seni daerah) yang diperdengarkan atau dibaca. Melalui resensi-resensi buku tersebut siswa mampung mengidentifikasi informasiinformasi yang terdapat di dalamnya. Selain itu struktur dan kebahasaan yang sudah sesuai dengan teori teks ulasan mampu membuat siswa mudah dalam mengidentifikasikan teks resensi tersebut.

Meskipun dilihat dari segi struktur dan kebahasaan keduabelas resensi tersebut sudah sesuai teori mengenai teks ulasan, pemilihan resensi dilihat dari segi topik atau tema juga perlu dilakukan. Hal tersebut karena resensi yang dijadikan bahan ajar harus disesuaikan dengan perkembangan psikologi siswa dan tema-tema yang sesuai dengan usia mereka.

Berdasarkan pembahasan mengenai relevansi rubrik resensi buku pada surat kabar Solopos edisi Januari-Desember 2017 sebagai bahan ajar bahasa Indonesia di Sekolah Menengah Pertama, dapat disimpulkan terdapat dua kategori yaitu cocok untuk dijadikan bahan ajar dan kurang cocok. Kategori cocok yaitu yang sudah memenuhi struktur dan kaidah kebahasaan serta memiliki topik atau tema yang pas, dan kategori kurang cocok yaitu resensi dengan tema yang tidak sesuai dengan perkembangan siswa. dari keduabelas resensi tersebut, resensi buku yang termasuk dalam kategori cocok untuk dijadikan bahan ajar 
yaitu resensi dengan judul Menyoal Laku Bebahasa, Memahami Teknologi Komunikasi A-Z, Jejak Karya ke-83 Mira Widjaya di Paris dan Remaja dan Asmara.

\section{Relevansi Rubrik Resensi Buku sebagai Bahan Ajar Teks Ulasan di SMA}

Duabelas resensi buku dari surat kabar Solopos edisi Januari-Desember 2017 yang menjadi objek penelitian dalam skripsi ini sesuai digunakan sebagai bahan ajar bahasa Indonesia di Sekolah Menengah Atas. Dilihat dari aspek strukturnya, resensiresensi tersebut sudah memenuhi kebutuhan materi mengenai teks ulasan. Struktur resensi atau teks ulasan yang dipelajari di SMA terdiri dari judul resensi, identitas buku, pendahuluan atau pembuka resensi, isi resensi, dan penutup. Kedua belas resensi yang dianalisis sudah memenuhi struktur tersebut. Kemudian dilihat dari aspek kebahasaan. Secara keseluruhan bahasa yang dipakai dalam resensi-resensi tersebut mudah dipahami oleh siswa. Selain itu, terdapat kata-kata yang mungkin baru sehingga juga mampu menambah perbendaharaan kosakata siswa.

Dilihat dari kompetensi dasar yang terdapat di dalam kurikulum 2013, resensi buku ini sesuai jika digunakan sebagai bahan ajar siswa SMA kelas XI. Kompetensi dasar yang berkaitan dengan penelitian ini terdapat pada kompetensi dasar 3.16 yaitu membandingkan isi berbagai resensi untuk menemukan sistematika sebuah resensi, dan 3.17 yaitu menganalisis kebahasaan resensi setidaknya dua karya yang berbeda. Selain itu, dari aspek pengetahuan dan keterampilan tentunya siswa di jenjang SMA lebih paham dari segi konteks karena mereka lebih berpengalaman dan mampu berpikir kritis dibandingkan dengan siswa SMP.

Berdasarkan pembahasan mengenai relevansi rubrik resensi buku pada surat kabar Solopos edisi Januari-Desember 2017 sebagai bahan ajar bahasa Indonesia di
Sekolah Menengah Atas, dapat disimpulkan bahwa semua resensi tersebut cocok untuk dijadikan bahan ajar. Hal tersebut karena resensi buku sudah memenuhi dua aspek yaitu struktur dan kebahasaan. Struktur resensi yaitu terdiri dari judul resensi, identitas buku, pendahuluan, isi, dan penutup. Kemudian topik resensi yang berbeda-beda sebenarnya menjadi nilai tambah karena bisa menambah wawasan dan pengetahuan siswa.

\section{SIMPULAN}

Berdasarkan hasil analisis data dan pembahasan yang telah diuraikan di atas, dapat disimpulkan bahwa rubrik resensi buku pada surat kabar Solopos edisi JanuariDesember 2017 merupakan wacana yang padu dan utuh. Hal tersebut didukung oleh struktur wacana yang lengkap terdiri paragraf pembuka, paragraf penghubung atau isi wacana, dan paragraf penutup. Selain itu juga didukung aspek tekstual yang meliputi topik wacana, aspek gramatikal, dan aspek leksikal. Aspek gramatikal yang ditemukan yaitu pengacuan, penyulihan, pelesapan, dan konjungsi, sedangkan aspek leksikal yang ditemukan yaitu repetisi, sinonimi, antonimi, kolokasi, dan ekuivalensi. Bentuk kata yang ditemukan pada rubrik resensi berupa kata ganti, kata konjungsi, sinonim, dan antonim. Analisis kontekstual dalam rubrik resensi buku pada surat kabar Solopos edisi Januari-Desember 2017 dapat dipahami melalui empat prinsip penafsiran, yaitu: prinsip penafsiran personal, prinsip penafsiran lokasional, prinsip penafsiran temporal, dan prinsip analogi. Keduabelas resensi yang telah dianalisis tersebut berpotensi untuk digunakan dan dikembangkan sebagai bahan ajar pembelajaran bahasa Indonesia di SMP dan SMA. Hal tersebut dilihat berdasarkan kesesuaian antara resensi buku dengan kompetensi dasar yang terdapat dalam kurikulum 2013, dan teori mengenai bahan 
ajar serta teori teks ulasan yang baik dan

\section{REFERENSI}

Badara, A. (2013). Analisis Wacana: Teori, Metode, dan Penerapannya pada Wacana Media. Jakarta: Kencana Prenada Media Group

Jamilah, R. (2017). Pengembangan Bahan Ajar Teks Ulasan Berbasis Proyek pada Siswa Kelas VIII SMP Negeri 2 Bululawang. NOSI, Volume 5 Nomor 3, 395-409.

Kusmana, S. (2014). Kreativitas Menulis. Yogyakarta: Penerbit Ombak (Anggota IKAPI)

Lestari, I (2013). Pengembangan Bahan Ajar Berbasis Kompetensi. Padang: Akademia Permata

Mahsun. (2014). Teks Pembelajaran Bahasa Indonesia Kurikulum 2013. Jakarta: Raja Grafindo Persada

Meza, Y. F., Mustofa, A., \& Karomani. (2015). Pembelajaran Menulis Teks Ulasan pada Siswa Kelas VIII SMP Negeri 4 Metro Tahun Pelajaran 2014/2015. Jurnal Kata (Bahasa, Sastra, dan Pembelajarannya), 1-9.

Mulyana. 2005. Kajian Wacana Teori, Metode, dan Aplikasi Prinsip-prinsip Analisis Wacana. Yogyakarta: Penerbit Tiara Wacana

Odoom, F. O. (2014). Why Write Book Reviews?. University Of Technology Sidney. Volume 56 Nomor. 1.

Oka, I.G.N., \& Suparno. (1994). Linguistik Umum. Jakarta: Direktorat Jenderal Pendidikan Tinggi Departemen Pendidikan dan Kebudayaan

Rohmadi, M., \& Nasucha, Y. (2010). Paragraf: Pengembangan dan Implementasi. Yogyakarta: Media Perkasa

Saddhono, K. (2009). Analisis Wacana. Surakarta: Sebelas Maret University Press. benar sebagai materi ajar.

Slamet, St. Y. (2007). Dasar-Dasar Pembelajaran Bahasa dan Sastra Indonesia di Sekolah Dasar. Surakarta: LPP UNS dan UPT.

Sugiyono. (2016). Memahami Penelitian Kualitatif. Bandung: Penerbit Alfabeta

Sumarlam. (2006). Analisis Wacana Tekstual dan Kontekstual. Surakarta: FSRD Universitas Sebelas Maret

Wijana, I. D. P., \& Rohmadi, M. (2010). Analisis Wacana Pragmatik. Surakarta: Yuma Pustaka 